\title{
Web-Based Learning Media for Practical Learning Strategy of Office Administration Program in Vocational School
}

\author{
$1^{\text {st }}$ Anis Susanti \\ The Faculty of Teacher Training and \\ Education \\ Sebelas Maret University \\ Jl. Ir. Sutami No. 36 A Kentingan \\ Surakarta, Indonesia
}

\author{
$2^{\text {nd }}$ Wiedy Murtini \\ The Faculty of Teacher Training and \\ Education \\ Sebelas Maret University \\ Jl. Ir. Sutami No. 36 A Kentingan \\ Surakarta, Indonesia
}

\author{
$3^{\text {rd }}$ Harini \\ The Faculty of Teacher Training and \\ Education \\ Sebelas Maret University \\ Jl. Ir. Sutami No. 36 A Kentingan \\ Surakarta, Indonesia
}

\begin{abstract}
This paper is written for the purpose of exploring in details about the needs of web-based learning media in vocational school. Nowadays almost every office works are done by utilization of technology called office automation. Students are not capable of understanding the learning material easily without appropriate learning media. Teacher needs develop the learning media based on technology, thus the student can easily simulate the process of office work in the classroom to improve their competency. The population of this study was all eleventh grade students of office administration who attended personnel administration lesson. The sample of this study used a simple random sampling technique to obtain 81 samples. This study is descriptive quantitative research with survey technique. The result of the research shows that $70 \%$ students said difficult to understand personnel administration lesson, $68 \%$ students agree that personnel administration material is interesting, 68\% said that the media used by the teacher is appropriate enough but still need to be developed, 99\% agree about the development of web-based learning media for practical learning, and $96 \%$ of the students agree about the learning media development in personnel administration subject to enhance their understanding of procedural knowledge
\end{abstract}

Keywords: web-based learning, media, vocational school

\section{INTRODUCTION}

Currently the application of appropriate information and communication technology (ICT), is believed to support and facilitate the completion of office work and has an impact on the emergence of a variety of office automation technologies. Integrating the various information technology platforms and communication channels; the latter authors find that integrating the various collaboration technologies available, ranging from post mail to teleconferences, videoconferences, and virtual collaboration, was essential to the performance of scientific teams in office work [1]. ICT adoption process has touched various fields of work, ranging from finance, staffing, facilities and infrastructure, archives and other fields. It also has an impact on formal education with the adjustment of the curriculum in a vocational school in Indonesia so the adoption and application of technology in the end needs to be balanced with competent human resources in using and utilizing the available technology.

In Indonesia, Sekolah Menengah Kejuruan (SMK) as a form of vocational education under the auspices of the Direktorat Pembinaan Sekolah Menengah Kejuruan, is a vocational education institution oriented to the formation of life skills, which is to train students to master the skills needed by the industry, entrepreneurship, as well as forming life skills. Mastery of student skills needed by the industry is obtained through the learning process. Learning activities in SMK are more emphasized on the good practices done in schools and industrial work practices, thus SMK graduates are expected to have experience and ready to enter the workplace.

The learning process that emphasizes the practical skill is contained in the subjects of the related skills program. Practical subjects, divided into three groups namely $\mathrm{C} 1$ for basic areas of expertise, $\mathrm{C} 2$ for basic skill programs and $\mathrm{C} 3$ for competency skills subjects. Practical subjects that emphasize students' understanding are in the $\mathrm{C} 3$ or subjects for competency skills in carrying 
out industrial work practices accordance with their skills program. Each skill program has a different outcome. One of the existing skills programs in SMK in accordance with the decree of Direktur Jenderal Pendidikan Dasar dan Menengah No: 130

/ D / KEP / KR / 201 in 2017 on Curriculum Structure of Vocational Education is the Office Management with the Competence of Office Automation. The previous program is Office Administration. Based on the decree of the Minister of Manpower of the Republic of Indonesia No. 183 / 2016 on the Indonesian Qualification Framework (SKKNI) in Supporting Activities Office and Other Supporting Activities Professional Administration Category, Office Administration skill program aims to prepare competent graduates of administrative office, junior administrative assistant (junior secretary), administrative assistant (secretary), executive administrative assistant (executive secretary), office administrative manager and corporate secretary.

One of the vocational schools that opened the Office Administration skills program is SMK Negeri 1 Bawang in Banjarnegara. Based on preliminary observations, the competencies studied in practical subjects by students and then most often students do in workplace learning are administrations, from the process of producing, receiving, collecting, copying and documenting data/information and others obtained in the work unit. In fact, during the learning process at school, students find it difficult to understand practical subjects contained procedural knowledge.

Based on the results of interviews with teachers of personnel administration subjects, she mentioned that for three years on subjects, learning was more understanding of government regulations on labor regulations and often related to articles of the Civil Servant (PNS) provisions. This makes students difficult to understand the material because it is rarely practice. A meta-analysis of the effectiveness of web-based instruction and classroom instruction showed that web-based instruction was $6 \%$ more effective than classroom instruction for teaching declarative knowledge, and equally effective for teaching procedural knowledge [2]. Therefore, delivery media (web- based or face-to face) is less important than instructional methods [3-4] in developing declarative and procedural knowledge.

\section{II.METHODS}

The population of this study was all eleventh grade students of office administration who attended practical learning of personnel administration subject. The sample of this study used a simple random sampling technique to obtain81 samples. This study is descriptive quantitative research with survey technique. In this study, the author determines the needs of web-based learning media in the form of interactive multimedia automation of personnel administration to enhance students' ability to understand the learning materials.

\section{RESULTS AND DISCUSSION}

From the results of interviews with teachers of personnel administration subjects, there are gaps, namely the basic competencies that must be mastered students have not supported with adequate learning media so that the need for the use of information and communication technology from the media used. As revealed by Kim that students can't understand theories and concepts clearly if the technology approach to practice in learning is lacking [5]. Damarjati reveals that the concept of learning in SMK requires the latest facilities for practice. The necessary facilities can be innovation in the development of learning media [6]. The teacher also stated that in the structure of the latest curriculum, there is a competency unit operating software applications with basic competence to apply the automation of personnel management during one semester (mostly from other basic competencies) so it is very necessary that the learning media can be used for student practice, so students do not get bored to learn the materials.

Media developed in the subjects of personnel administration in vocational schools can be interactive web-based multimedia learning so that the media allows to be used as a simulation media in applying the automation of document employment. Learning using the web media platform can be a solution for storing and sharing learning materials more easily because of 
centralized information [7]. Web-based learning in the media will make students more independent in building complex knowledge by linking scientific ideas and facilitating teachers in monitoring the learning activities of each student [8]. Web-based interactive multimedia can be used for game simulation in learning, it will make it easier for students to understand the material.

The results of Nkhoma et al. [9] found that learning with game simulation had a positive impact on cognitive learning outcomes. Game simulations supported with web-based interactive multimedia will suit the complexity of personnel administration materials, require a database and require data integration to generate documents. Such simulation media can be created by utilizing relational database (RDB). Utilizing $\mathrm{RDB}$ can make software more interactive and easier to organize different types of data formats [10].

The characteristics of basic competence in personnel administration in accordance with the K13 curriculum include: grouping employment policies, making employment documents (procurement, transfer, employee position, promotion, performance appraisal, and dismissal of employees) and managing individual employee documents. The basic competencies are ultimately expected to be practiced, and students can understand the flow by applying the automation of employee management. Through the use of technology in learning, students will more easily understand the taught material and support skills acquisition in accordance with the expected competence [11].

The results of the preliminary survey indicate that the students of eleventh grade office administration (XI AP) in SMK Negeri 1 Bawang still find it difficult to understand the personnel administration materials. Of the 81 students representing the XI AP 1, XI AP 2 and XI AP 3 classes, 57 students $(70 \%)$ stated that the personnel administration material is difficult to understand because the subject matter is related to the government regulations on employment and the articles that must be memorized (Figure 1).
Fig 1.

Is the subject of personnel administration difficult to underst and?

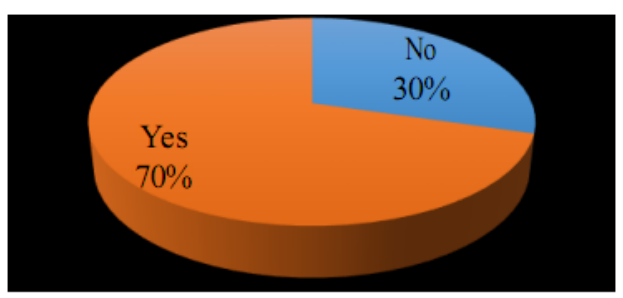

No $=$ Yes

From the results of preliminary observation is known that one of the subjects that are considered difficult to be understood by students is the subject of personnel administration or in the industrial workplace it named Human Resource Department (HRD). In terms of instructional media used by teachers, it has been combined only to be limited to theoretical learning in the classroom. Then viewed from the facet of the learning method in the discussion is quite interesting for students, but the students more often find their own information through the internet, then they feel worried about the material that does not match what will come out during the test (Figure 2). In addition, at the time of industrial work practice some students mention, get job duties to make structuring personnel documents. The job tasks are different when taught in schools, because students do not practice or simulate to know how to describe the flow of employment administration in the world of work.

Fig 2.

Is the subject of personnel administration interesting?

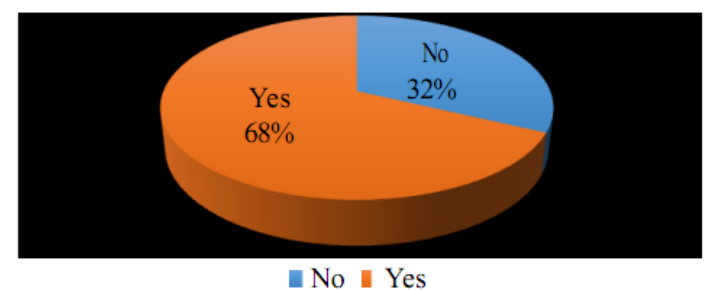

Whereas practical learning for vocational students is very important so that students can easily understand the theory of competency control, as expressed by Damarjati that practical learning for vocational students is important for 
the assessment of student success that must be "hands-on" or in accordance with the performance in the world of work [6]. All of the students agree about the learning media development in personnel administration subject to enhance their understanding.

Fig 3.

Is the learning media of personnel administration subject appropriate with the materials?

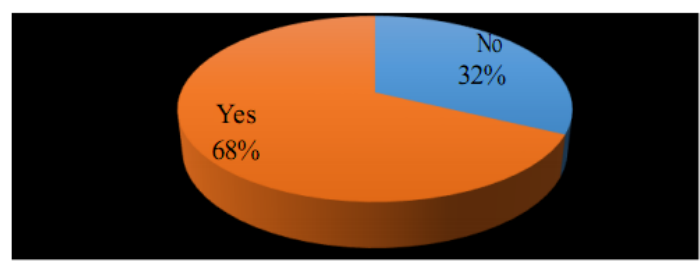

No 1 Yes

Then the results of student needs analysis showed from 81 students, $99 \%$ students stated the need for the development of learning media personneladministration so as not to bore and the material more easily understood. A total of $96 \%$ students from 81 students agree that the developed learning media can be used for practice in personnel administration learning because according to the student, if the learning is done by direct practice such as making the personnel document, then the students will be more familiar with the flow of personnel administration, not only memorize its provisions of the articles in government regulations (Figure 4).

Fig 4 .

Do you agree about the development of learning media in personnel administration subject for practical learning?

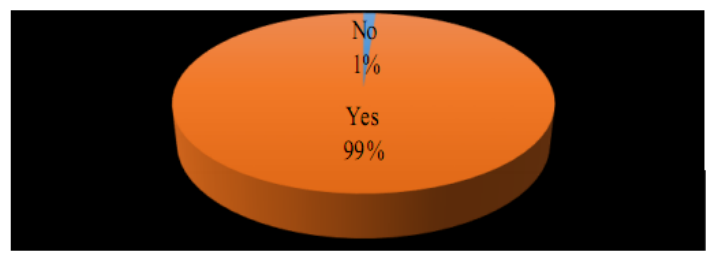

- No 1 Yes

In line with what Drake has expressed that teaching and learning activities that include group collaboration, task visualization and simulation through laptops and the Internet, hands-on experiments are elements that can enrich students' understanding [12]. Efforts that can be done to prepare competent human resources improve the quality of learning through the application of technology in the teaching learning process. The application is intended to train and familiarize students with job trends in the digital era demanding speed and accuracy. For example learning related to making documents in office automation using Microsoft Office software. The consequences of the automatic activities are also visible in the basic competence of applying the automation of personnel management that must be mastered by the students, so that the need for the development of interactive multimedia in order to support the process of learning practices.

Based on Figure 5 the students said that the development of media for personnel administration subject is needed (96\%). It is important to adopt technology in learning media, thus the students can understand materials easier. If technology is used properly, students can utilize technology as a resource for heightened knowledge and simplified way to achieve a grade [13]. The utilization of technology in personnel administration subject can make the practical learning for student easier and they can simulate the real office work in the classroom with the web-based learning media.

Fig 5.

Do you agree if the learning media is used for the practice of personnel administration?

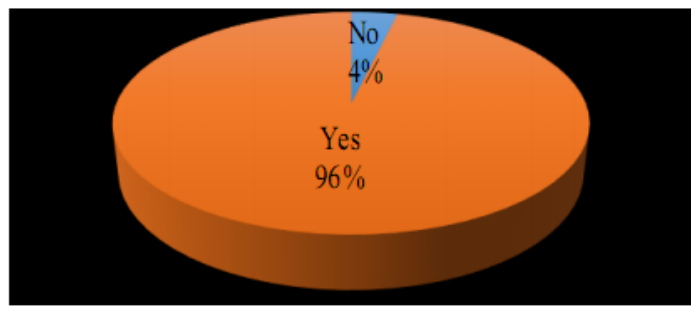

- No ॥ Yes

Technology can thoroughly assist in the efficacy of instructions when used correctly. Educators not only understand how to use the basic tools for the class; they must also use that comfort in such a way as to trigger interest, critical thinking, and the desire to create something [14]. With the development of technology, ICT has become an important component in the world of education change and is an integral part of a school curriculum [15]. ICTs are also considered a 
valuable teaching tool, and students seem to have the digital competence required in using ICT [16].

\section{CONCLUSION}

In this paper, from the survey authors determine the needs of web-based learning media for practical learning in personnel administration lesson to enhance students' understanding. The students' understanding of procedural knowledge should be supported by the utilization of appropriate media. In line with the previous research that $84 \%$ of all students as course participants agreed that the use of simulator contributed to the understanding of the problem [17]. Based on the above description, the author intends to develop interactive multimedia learning as a simulator for practical learning in the future as a solution to the problems found in the learning of personnel adminis tration.

\section{ACKNOWLEDGMENT}

This paper is supported by the Indonesia Endowment Fund for Education (LPDP). The author also gratefully acknowledge the helpful comments and suggestions of the reviewers, which have improved the presentation.

\section{REFERENCES}

[1] John E. Ettlie, Christopher Tucci, Peter T. Gianiodis, "T rust, integrated information technology and new product success", European Journal of Innovation Management, Vol. 20 Issue: 3 (2017) pp.406-427.

[2] Sitzmann, T., Kraiger, K., Stewart, D. and Wisher, R., "The comparative effectiveness of web-based and classroom instruction: A meta-analysis", Personnel Psychology, Vol. 59 (2006) pp. 623-664.

Clark, R.E., "Reconsidering research on learning from media", Review of Educational Research, Vol. 53 (1983) pp. 445-460.

[4] Clark, R.E., "Media will never influence learning”, Educational Technology Research and Development, Vol. 42 (1984) pp. 21-29.Bruno, F.B., Silva, T.L.K., Silva, R.P., \& Teixeira, F.G., "Web-based learning design tool," Campus-Wide Information Systems, Vol. 29 No. 4 (2012) pp. 201 212 .

[5] L.Kim,Technology, Learning, and Innovation: Experiences of Newly Industrializing Economies. Cambridge University Press, 2011.

[6] https://psmk.kemdikbud.go.id/konten/1869/ konseppembelajaran-di-sekolah-menengah- kejuruan.
F.B. Bruno, T.L.K. Silva, R.P. Silva, and F.G. Teixeira, "Web-based learning design tool", Campus-Wide Information Systems, Vol. 29 No. 4, 2012 pp. 201-212.

S.F. Petra, J. Jaidin, J. Perera, and M. Linn, "Supporting students to become autonomous learners: the role of web-based learning," The International Journal of Information and Learning Technology, Vol. 33 Iss 4 (2016) pp. 263-275.

[9] M. Nkhoma, J.Calbeto, N. Sriratanaviriyakul, T. Muang, Q.H. Tran, and T.K. Cao, "Towards an understanding of real-time continuous feedback from simulation games," Interactive Technology and Smart Education, Vol. 11 Iss 1 (2014) pp 4562.

[10] G. Nigrelli, M. Chiarle, A. Nuzzi, L. Perotti, G. Torta, and M. Giardino, "A web-based, relational dat abase for studying glaciers in the Italian Alps," Computers \& Geosciences, 51 (2013) 101-107.

[11] N.F. Hassan, S. Puteh, and R. Buhari, "Student understanding through the application of technology enabled active learning in practical learning," Procedia Social and Behavioral Science, 204 (2015) 318-325.

[12] J.E. Drake, M. Ahern, E. Roche, and E.Winner, "The value of making it by hand," Proceedings of the Biennial Congress of The International Association of Empirical Aesthetics, (2014) 174179

[13] Diem, R.A., "A positive or negative force for democracy: the technology instructional paradox", International Journal of Social Education, Vol. 21 No. 1 (2006) pp. 148-154

[14] L.P. Pate, "Technology implementation:impact on students' perception and mindset", The International Journal of Information and Learning Technology, Vol. 33 Iss 2 (2016) pp. 91-98.

[15] Papanastasiou, E.C., and Angeli, C., "Evaluating the use of ICT application in education: Psychometric properties of the survey of factors affecting teachers teaching with technology (SFAT3)", Educational Technology \& Society 11(1), 2008, 69-86.

[16] O.J. Lindberg, A.D. Olofsson and G. Fransson, "Same but different? An examination of Swedish upper secondary school teachers' and students' views and use of ICT in education", The International Journal of Information and Learning Technology, Vol. 34 Issue: 2 (2017) pp. 122-132.

V. Mkrttchian, M. Kljajic, A. Škraba, H.Yeranosyan and M.K. Borštnar, "Development of Educational Web-Based Simulator and its Evaluation", In Proceedings of the 17th World Congress The International Federation of Aut omatic Control Seoul, Korea, July 6-11, 2008 pp. 9802 9806. 